\title{
Kinetics of Antifibrillatory Effects of Bretylium: Correlation With Myocardial Drug Concentrations
}

\author{
JEFFREY L. ANDERSON MD, FACC \\ EUGENE PATTERSON \\ MARILYN CONLON \\ STANISLAW PASYK, MC) \\ BERTRAM PITT, MD, FACC \\ BENEDICT R. LUCCHESI. PhD, MD
}

Ann Arbor, Michigan
From the Departments of Internal Medicine and Pharmacology, and the Upjohn Center for Clinical Pharmacology, University of Michigan Medical School, Ann Arbor, Michigan. This study was supported in part by Faculty Girant 387448 from the Rackham Foundation of the University of Michigan, Ann Arbor, Michigan; a Career Development Grant in Clinical Pharmacology from the Upjohn Company, Kalamazoo, Michigan; and Grant HL 05806-19 from the National Heart, Lung, and Blood Institute, National Iristitutes of Health, Bethesda, Maryland. Manuscript received November 28, 1979; revised manuscript received April 21, 1980, accepted April 29, 1980.

Address for reprints: Benedict R. Lucchesi, MD Department of Pharmacology;, M6322 Medical Science Building, The University of Michigan Medical School, Ann Arbor, Michigan 48109.
To determine the kinetics of the antifibrillatory effects of bretylium tosylate and to assess the relative importance of myocardial versus serum drug concentrations, studies were performed in 32 dogs after they received bolus injections of bretylium tosylate $(6 \mathrm{mg} / \mathrm{kg}$ or $2 \mathrm{mg} / \mathrm{kg}$ body weight) or saline solution. Parallel determinations were made of drug concentrations in serum and myocardium, together with antifibrillatory and electrophysiologic effects, both with and without 2 minutes of coronary ischemia produced by temporary coronary ligation. Serum bretylium concentration decreased rapidly after intravenous injection, whereas myocardial concentrations increased gradually, peaking at 1.5 to 6 hours in both open and closed chest dogs. The ratio of myocardial to serum drug concentration increased to 6.4 to 12.6 at 12 hours. Parallel elimination of the drug in serum and myocardium occurred thereafter, with elimination half-life of 10.5 hours (closed chest dogs).

Electrophysiologic and antifibrillatory effects paralleled myocardial rather than serum drug kinetics with peak effects at 3 to 6 hours. The ventricular effective refractory period was 24 to $26 \mathrm{~ms}$ greater at 3 hours in dogs treated with the drug than in those receiving saline solution. The ventricular fibrillation threshold increased 6 to 10 -fold after $2 \mathrm{mg} / \mathrm{kg}$ of the drug was given at 3 to 6 hours in dogs both with and without ischemia in comparison with that in control animals treated with saline solution. The average increase in threshold exceeded 12-fold after administration of $6 \mathrm{mg} / \mathrm{kg}$ of the drug ( 2 minutes to 12 hours). The repetitive ventricular response threshold 3 hours after drug administration increased 5-fold after $2 \mathrm{mg} / \mathrm{kg}$ and 18 -fold after $6 \mathrm{mg} / \mathrm{kg}$ of the drug was administered in dogs with or without ischemia.

These studies elucidate canine serum and myocardial drug kinetics of bretylium, quantify the prolonged antifibrillatory effect of this drug with its delayed maximal effect and emphasize the importance of tissue levels of bretylium in determining drug action.

Rational therapy with antiarrhythmic drugs is predicated on an understanding of pharmacokinetics and mechanisms of action., ${ }^{1,2}$ Therapeutic effects depend on drug concentrations at sites of action. In the absence of techniques to determine concentrations at myocardial sites, drug concentrations in blood have been used to estimate expected drug response or adverse effects. However, these correlations may not be valid in drugs heavily concentrated in myocardial tissue, particularly during short-term administration when conditions of equilibrium do not apply. ${ }^{2}$

Bretylium tosylate is an antiarrhythmic drug recently approved for general use in therapy of refractory ventricular tachyarrhythmia. ${ }^{3,4}$ Initially introduced more than 20 years ago as an antihypertensive drug, it proved ineffective because of rapid development of tolerance and erratic absorption with oral dosing. Bacaner ${ }^{5}$ first discovered its antifibrillatory potential more than 10 years ago, and championed its appli cation as antiarrhythmic agent. 
During short-term administration, bretylium displays a biphasic effect on the cardiovascular system.,7 An initial increase in blond pressure accompanied by tachycardia is a manifestation of local catecholamine release at adrenergic nerve endings. ${ }^{6,8}$ This is followed by a decrease in blood pressure and relative bradycardia, a manifestation of the drug's antiadrenergic effect. The latter is usually the predominant effect. The electrophysiologic effects of bretylium are complex and their relation to antiarrhythmic effects is as yet unclear. ${ }^{9,10}$ The direct antiadrenergic as well as early sympathomimetic effects during administration have all been mentioned as potential contributing mechanisms. An increase in the ventricular fibrillation threshold was described more than a decade ago in dogs treated with bretyllium on a short-term basis, ${ }^{5}$ but more recently questions concerning the drugs antifibrillatory as well as its antiarrhythmic effects have again been raised. ${ }^{4}$

The chemical and pharmacologic effects of bretylium place it in a class separate from other currently available antiarrhythmic drugs. ${ }^{11,12}$ Studies to date have inadequately elucidated the disposition and mechanism of action of bretylium. Similarly, the onset and time course of antiarrhythmic effect, blood distribution and elimination kinetics and tissue kinetics have not been well defined. A reliable assay for bretylium to allow such studies has heretofore not been available, and a therapeutic range for drug concentrations has not been established.

Recently, a sensitive and reliable gas chromatographic assay for bretylium was developed in our laboratory, ${ }^{13}$ which has allowed us to examine several of these questions about the drug's action. Specifically, our purpose was to investigate the time course of antifibrillatory effects of bretylium after bolus injection in dogs, and to correlate the drug's antiarrhythmic effects with both serum and myocardial concentrations. The results confirm the marked antifibrillatory effect of this agent and emphasize the importance of tissue kinetics in determining this behavior.

\section{Methods}

Serum and tissue pharmacokinetic studies in open chest dogs: Ten male mongrel dogs weighing 10 to $20 \mathrm{~kg}$ were anesthetized with sodium pentobarbital, $30 \mathrm{mg} / \mathrm{kg}$ bodyweight intravenously. The left common carotid artery was exposed and cannulated for continuous monitoring of blood pressure. The left external jugular vein was cannulated as an access route for administration of bretylium tosylate. The right femoral vein was also cannulated, and a catheter placed into the inferior vena cava above the level of the renal veins and below the level of the hepatic veins. Percutaneous electrode leads were attached to generate an electrocardiogram for continuous monitoring. The chest was opened with cautery in the fourth left intercostal space and the heart was suspended in a pericardial cradle.

Bretylium tosylate was administered intravenously over 60 seconds in doses of $6 \mathrm{mg} / \mathrm{kg}$ (seven dogs) or $2 \mathrm{mg} / \mathrm{kg}$ (three dogs). Blood' samples $(3 \mathrm{ml}$ ) were taken for serum bretylium determinations at the following times after injection: $0,1,2$, $4,8,15$ and 30 minutes and $1,2,4,8$ and 12 hours. Full thickness myocardial tissue samples $(50$ to $100 \mathrm{mg}$ ) were taken with a cylindrical biopsy punch ( $4 \mathrm{~mm}$ in diameter) from the left ventricular free wall at 30 minutes, 90 minutes, 6 hours and 12 hours after drug injection. The dogs were killed at 12 hours, and tissue samples from the left and right ventricles, interventricular septum, anteromedial papillary muscle, mitral valve and atria were taken immediately post mortem for analysis of cardiac distribution of bretylium. Tissue samples were carefully blotted dry, weighed and dissolved in $500 \mu$ liters of 16 normal sodium hydroxide. Solutions were neutralized with $800 \mu$ liters of 7 normal hydrochloric acid. Solubilized tissue and serum were analyzed for bretylium concentrations using a high resolution gas chromatographic assay recently developed in this laboratory, and sensitive to $1 \mathrm{ng} / \mathrm{ml}$ bretylium. ${ }^{13}$ Samples were analyzed in duplicate or triplicate and results expressed as $\mu \mathrm{g} / \mathrm{ml}$ or $\mu \mathrm{g} / \mathrm{g}$ of bretylium free base in serum or tissue, respectively.

Long-term single dose drug kinetics in closed chest dogs: To determine pharmacokinetics in tissue and serum of single dose bretylium in intact animals, six male mongrel dogs weighing 10 to $20 \mathrm{~kg}$ were given a single dose of $6 \mathrm{mg} / \mathrm{kg}$ of bretylium tosylate intravenously and observed for 48 to 96 hours (median 72 hours). Using a clean surgical technique, we exposed and cannulated the right internal jugular vein with a 9 French catheter introduced while the animal was sedated with sodium pentobarbital $(30 \mathrm{mg} / \mathrm{kg})$. Continuous electrocardiographic monitoring (lead II) was used during drug administration and sampling.

The drug was next administered over 60 seconds. Cardiac tissue samples were taken from the right interventricular septum using the Stanford right ventricular bioptome as described by Mason ${ }^{14}$ and adapted to dogs. Three to five individual biopsy specimens were taken at each time point, to yield at least $5 \mathrm{mg}$ of myocardial tissue per sample time. Simultaneously, venous blood ( 3 to $4 \mathrm{ml}$ ) was withdrawn for drug assay. After drug injection, tissue and blood samplings were performed at 30 minutes and $3,6,12,24,36,48$ and 72 hours.

After initial sampling, the dogs were allowed to recover from pentobarbital anesthesia, then reanesthetized lightly each 12 to 24 hours to provide sufficient sedation for subsequent biopsy samplings. Between sampling times, dogs were fed and watered, and allowed free activity in their cages. After the final sampling point, they were killed and tissue samples from the representative myocardial sites earlier noted were taken for confirmation of final myocardial drug concentration and intracardiac distribution of drug. Samples were processed and analyzed as previously described.

Ventricular fibrillation threshold determination: ' $T o$ determine the effect of bretylium on the ventricular fibrillation threshold, 17 male mongrel dogs weighing 10 to $20 \mathrm{~kg}$ were given bretylium intravenously in doses of $2 \mathrm{mg} / \mathrm{kg}$ ( $6 \mathrm{dogs}$ ) or $6 \mathrm{mg} / \mathrm{kg}$ ( $4 \mathrm{dogs}$ ) of the tosylate salt or normal saline solution (7 dogs) over 60 seconds. Serial determinations of the ventricular fibrillation threshold were made. ${ }^{15,16}$ Dogs were prepared while sedated with sodium pentobarbital $(30 \mathrm{mg} / \mathrm{kg})$. The common carotid artery was isolated and cannulated for constant arterial pressure monitoring using a Statham pressure transducer. The left external jugular vein was cannulated as a venous access site for drug administration. With use of cautery, a left thoracotomy was performed in the fourth intercostal space and the heart was suspended in a pericardial cradle.

A biopolar electrode, consisting of silver-silver chloride electrodes $1 \mathrm{~mm}$ in diameter and imbedded in an acrylic plaque, was sewn onto the anterior right ventricle. Electrodes were cleaned daily with emery paper. A pacing electrode was attached to the left atrium using an alligator clip to allow for pacing with a Grass model SD5 stimulator. A plunge bipolar electrode ( $1 \mathrm{~cm}$ in length) was sewn into the surface of the left 
ventricle and used to determine the effective refractory period. Lead II of the electrocardiogram was monitored continuously on a Tektronix oscilloscope. The left anterior descending coronary artery was dissected free in its mid portion. A double ligature was passed under the artery and the vessel was temporarily occluded for 2 minutes for the determination of thresholds during ischemia, as noted later. Ventricular effective refractory periods, ventricular fibrillation thresholds (without and with ischennia) and repetitive ventricular response thresholds were all measured in the same series of dogs.

Determination of ventricular fibrillation threshold was performed with a modification of the method of Kroll and Lucchesi. ${ }^{16}$ Animals were paced from the atrium at 175 beats/min. Four ms fibrillation pulses of 60 hertz frequency and $200 \mathrm{~ms}$ total duration were synchronized to the pacing stimulus with a $50 \mathrm{~ms}$ delay, so as to scan the $\mathrm{T}$ wave in the vulnerable period of the heart. The current delivered was measured exactly by recording voltage drop across a precision $1,000 \mathrm{ohm}$ resistor in series with the electrodes. Current intensity was increased in $0.5 \mathrm{~mA}$ increments to $5 \mathrm{~mA}$, then in $1 \mathrm{~mA}$ increments to $10 \mathrm{~mA}, 2 \mathrm{~mA}$ increments to $20 \mathrm{~mA}$ and 5 $\mathrm{mA}$ increments to $50 \mathrm{~mA}$ until ventricular fibrillation developed. Three attempts at each current level were made. The current intensity inducing, sustained ventricular fibrillation was defined as the ventricular fibrillation threshold. When fibrillation occurred, the heart was immediately defibrillated using a capacitor discharge direct current defibrillator charged to 10 to 15 joules. The heart was allowed to recover for a minimum of 15 minutes after each determination.

The schedule for determination of ventricular fibrillation threshold was as follows: Before drug administration, a control determination was made in the absence of ischemia. After a 15 minute rest interval, the mid anterior descending coronary artery was ligated and control ischemia threshold determinations were begun after 2 minutes. The ligature was released after fibrillation was precipitated, and the heart was promptly defibrillated. A 30 minute recovery period was allowed and drug or saline solution was administered. Two minutes after injection the threshold was determined; 30 minutes after the drug was given, threshold measurements were repeated; a 15 minute interval was allowed and ischemic threshold was determined. Similar threshold determinations without and with ischemial were made at 90 minutes and 3,6 and 12 hours after injection. Adequate hydration was provided to maintain blood pressure in the normal range over the 12 hour period of study.
Ventricular effective refractory period and response threshold: Ventricular response threshold was measured at the beginning of each determination of ventricular fibrillation threshold. The ventricular response threshold was defined as the minimal current required to induce a ventricular premature beat in one to three attempts.

The left ventricular effective refractory period was defined as the longest $\mathrm{Q}-\mathrm{S}_{2}$ interval at which a premature impulse $\left(\mathrm{Q}-\mathrm{S}_{2}\right)$ consistently failed to cause ventricular depolarization; this refractory period was assessed just before each determination of ventricular fibrillation threshold. To make this determination, ventricular extrastimuli $\left(S_{2}\right)$ were introduced after every eight paced sinus beats at two to three times diastolic threshold through a plunge bipolar electrode in the left ventricle. $\mathrm{Q}-\mathrm{S}_{2}$ intervals were reduced by 5 to $10 \mathrm{~ms}$ until ventricular capture failed.

Repetitive ventricular response threshold: During the determinations of ventricular fibrillation threshold, the current at which more than two premature complexes were elicited by the fibrillation pulse (during at least one of three trials at a given current level) was defined for purposes of this study as the repetitive ventricular response threshold.

'Three to four ml of blood was withdrawn at the time of each threshold determination, to enable comparisons to be made between serum bretylium concentrations and drug effects. Samples were obtained at 2,30 and 90 minutes and 3,6 and 12 hours, and analyzed as previously described. Immediately after testing at 12 hours, the animal was killed and a $1 \mathrm{~g}$ tissue sample obtained from the left ventricle. Tissue analysis for bretylium was performed as previously noted.

Analysis of data: Electrophysiologic variables and serum and tissue drug concentrations were plotted as mean \pm standard error of the mean versus time for each separate group of animals. Drug elimination constants were determined by a linear regression program. Differences in mean responses of two or three groups at a given time were analyzed with Student's $t$ test or with analysis of variance for pairwise comparisons. ${ }^{17}$ When geometric response in the group receiving $6 \mathrm{mg} / \mathrm{kg}$ substantially violated the equal variance assumption (that is, repetitive ventricular response threshold, nonischemic dogs), treatment responses were analyzed independently with use of the $t$ test. Paired $t$ testing was used to compare response of a given variable in animals under two conditions. Similarity in response of different variables at a given time was sought using a correlation program. Significance was assumed at a probability (p) level of $<0.05$. For purposes of analysis, a (minimal) ventricular fibrillation threshold of $50 \mathrm{~mA}$ was
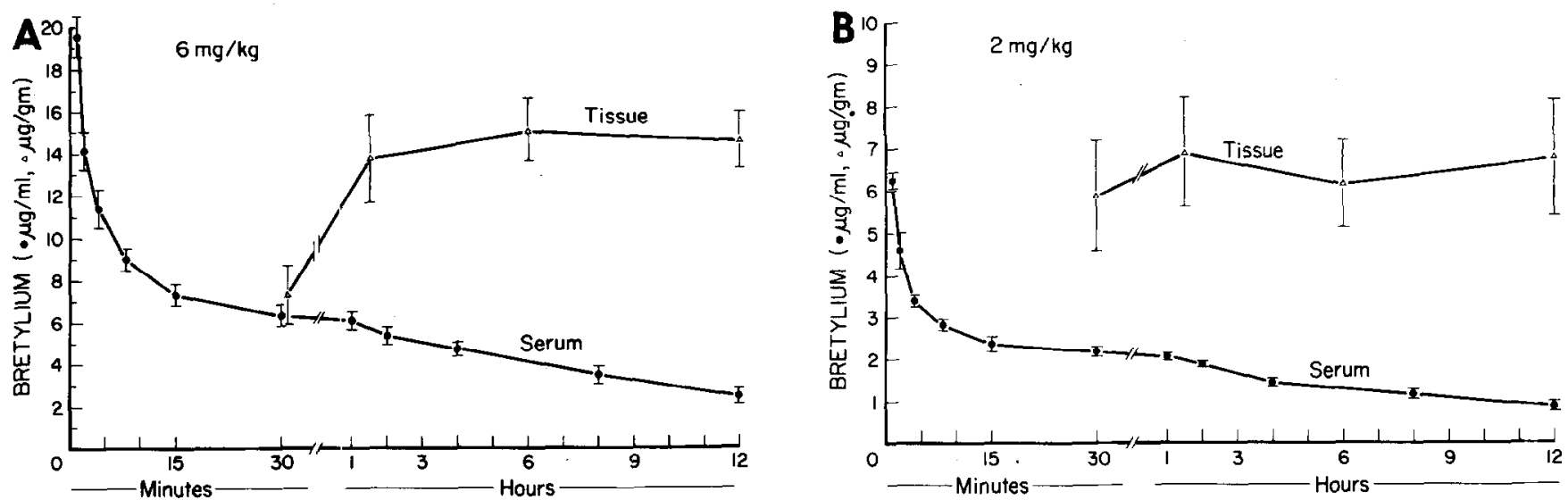

FIGURE 1. Concentrations of bretylium tosylate in serum and myocardial tissue after injection of $6 \mathrm{mg} / \mathrm{kg}$ (A) and $2 \mathrm{mg} / \mathrm{kg}$ (B) intravenously over 60 seconds in open chest dogs (seven and three dogs, respectively). Results given as mean \pm standard error of the mean. 
assigned in instances where the measureable threshold was exceeded.

\section{Results}

Serum and tissue bretylium in open chest dogs: After intravenous injection of $6 \mathrm{mg} / \mathrm{kg}(\mathrm{n}=7)$ of bretylium tosylate, in seven open chest dogs serum bretylium concentration decreased rapidly along a curvilinear (biexponential) curve from a peak of $19.6 \pm$ $1.1 \mu \mathrm{g} / \mathrm{ml}$, at 1 minute after injection, to $6.5 \pm 0.4 \mu \mathrm{g} / \mathrm{ml}$ at 30 minutes and $2.5 \pm 0.3 \mu \mathrm{g} / \mathrm{ml}$ at 12 hours (Fig. $1 \mathrm{~A}$ ). Distribution half-life ( $t / 2$ ) was approximately 3 minutes and terminal t $1 / 29.1$ hours. Myocardial drug concentration, in contrast, increased progressively with respect to serum drug concentration over the 12 hour period. Tissue bretylium was similar to serum bretylium at 30 minutes $(7.3 \pm 1.4 \mu \mathrm{g} / \mathrm{g})$, increased rapidly by 90 minutes $(13.7 \pm 1.2 \mu \mathrm{g} / \mathrm{g})$, peaked by 6 hours $(15.1 \pm 1.5$ $\mu \mathrm{g} / \mathrm{g})$ and remained at a plateau elevation at 12 hours $(14.6 \pm 1.3 \mu \mathrm{g} / \mathrm{g})$. The ratio of myocardial to serum bretylium increased progressively throughout the study to $1.2 \pm 0.3$ by 30 minutes and to $6.4 \pm 1.0$ at 12 hours.

The cardiac distribution of bretylium is shown in Figure 2. At 12 hours significant correlations existed in bretylium concentrations in the left ventricle (14.6 \pm $1.3 \mu \mathrm{g} / \mathrm{g})$, right ventricle $(14.3 \pm 1.5 \mu \mathrm{g} / \mathrm{g})$, interventricular septum $(14.6 \pm 1.6 \mu \mathrm{g} / \mathrm{g})$ and anteromedial papillary muscle $(14.0 \pm 1.6 \mu \mathrm{g} / \mathrm{g} ; \mathrm{p}<0.01$ for all correlations). Atrial bretylium concentration was slightly although significantly lower $(12.2 \pm 1.2 \mu \mathrm{g} / \mathrm{g}$; correlation $\mathrm{p}>0.05$ ). In contrast, the mitral valve leaflet, a relatively avascular tissue, accumulated bretylium to a concentration of only $2.0 \pm 0.3 \mu \mathrm{g} / \mathrm{g}$.

After injection of $2 \mathrm{mg} / \mathrm{kg}$ of bretylium tosylate (three dogs), serum bretylium concentration decreased along a multiphasic curve similar to that for the larger dose (Fig. 1B). Serum bretylium declined from $6.25 \pm$ $0.14 \mu \mathrm{g} / \mathrm{ml}$ at 1 minute after injection to $2.19 \pm 0.08$ $\mu \mathrm{g} / \mathrm{ml}$ at 30 minutes and to $0.87 \pm 0.10 \mu \mathrm{g} / \mathrm{ml}$ at 12 hours. Myocardium concentrated bretylium heavily at this dose as well, with tissue bretylium maintaining a

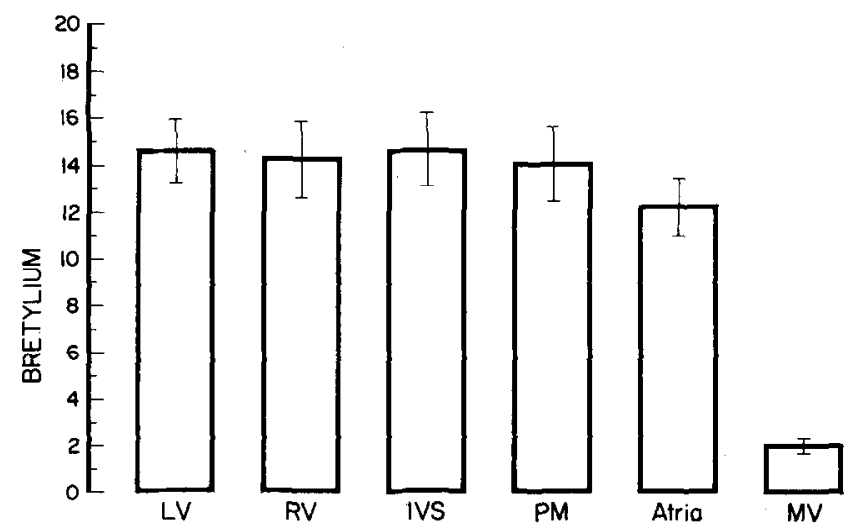

FIGURE 2. Cardiac distribution of bretylium $(\mu \mathrm{g} / \mathrm{g})$ at 12 hours in the seven dogs in Figure $1 \mathrm{~A}$. IVS = interventricular septum; LV = left ventricle; $M V=$ mitral valve leaflet tissue; $P M=$ anteromedial papillary muscle; $\mathrm{RV}=$ right ventricle. Results given as mean \pm standard error of the mean. plateau of nearly $7 \mu \mathrm{g} / \mathrm{g}$ between 90 minutes and 12 hours. A progressive increase in the ratio was $8.5 \pm$ 2.8 .

Long-term serum and tissue bretylium in closed chest dogs: Serum and myocardial bretylium concentrations measured in closed chest dogs allowed to recover consciousness are presented in Figure 3. Myocardial tissue was obtained by transvenous endomyocardial biopsy from the right interventricular septum in six dogs at various time points after $6 \mathrm{mg} / \mathrm{kg}$ of bretylium was injected (see methods). The accuracy of measurements obtained with endomyocardial biopsy samples was confirmed by comparison with larger samples obtained when the dogs were killed. Serum and cardiac bretylium concentrations were similar at 30 minutes $(7.15 \pm 0.59$ and $7.85 \pm 0.68 \mu \mathrm{g} / \mathrm{mg}$, respectively), with a mean tissue to serum ratio of $1.2 \pm 0.1$. These measurements were also similar to those at 30 minutes in closed chest dogs (Fig. 1A). Serum bretylium then continued to decrease in a nonlinear exponential fashion to $1.35 \pm 0.07 \mu \mathrm{g} / \mathrm{ml}$ at 12 hours. This somewhat smaller concentration, when compared with the 12 hour value in open chest given bretylium on a short-term basis, may reflect improved renal excretion in these lightly anesthetized intact animals. Between 12 to 24 and 72 hours, elimination followed a log-linear course, with an elimination rate constant $(\lambda 1-\mathrm{s})$ by linear regression analysis of $0.0663 \pm 0.008$ hour $^{-1}$, and an elimination half-life from serum ( $1 / 2-\mathrm{s}$ ) of 10.4 hours (harmonic mean).

Myocardial bretylium concentration increased after 30 minutes to peak levels at 3 and 6 hours of $11.3 \pm 0.7$ and $13.0 \pm 2.3 \mu \mathrm{g} / \mathrm{g}$, respectively. Myocardial concentration of the drug persisted at this high level until 12 hours $(11.2 \pm 1.6 \mu \mathrm{g} / \mathrm{g})$, then decreased in parallel with serum bretylium concentration between 24 and 72 hours from $6.25 \pm 0.91$ to $0.37 \pm 0.05 \mu \mathrm{g} / \mathrm{g}$. Tissue elimination rate constant $(\lambda 1-\mathrm{m})$ between 24 and 72 hours was $0.0662 \pm 0.009$ hour $^{-1}$, virtually identical to that for serum ( $\lambda 1$-s). Myocardial elimination half-life ( $\mathrm{t} 1 / 2-\mathrm{m})$ was 10.5 hours. The ratio of myocardial to serum bretylium in this interval averaged $12.6 \pm 1.9 \mu \mathrm{g} / \mathrm{g}$ per $\mu \mathrm{g} / \mathrm{ml}$ in the six dogs. These data indicate, in the intact animal, marked myocardial concentration of bretylium, with pseudoequilibrium (parallel elimination) being first established between 12 and 24 hours after single dose injection. Myocardial bretylium was still easily detectable by our assay at 72 hours.

Effects on effective refractory period and response threshold: Bretylium injections caused a time-dependent increase in the left ventricular effective refractory period (Fig. 4). The effective refractory period was unaffected by determination of the ventricular fibrillation threshold, including cardioversion, as shown by the comparability of refractory periods before and after control fibrillation threshold measurement in each group ( $p=$ difference not significant). Each of the two control refractory period measurements were also comparable among the three groups. However, after injection of bretylium, significant divergence in response among treated and control groups developed by 90 minutes $(\mathrm{p}=0.007)$ and persisted through 12 hours 
FIGURE 3. Bretylium concertrations in serum $(\mu \mathrm{g} / \mathrm{ml})$ and myocardial tissue $(\mu \mathrm{g} / \mathrm{g})$ in closed chest dogs after bolus injection of $6 \mathrm{mg} / \mathrm{kg}$ of the drug. Tissue samples obtained by transvenous endomyocardial biopsy. All six dogs were observed for $\mathbf{4 8}$ hours, three for 72 hours and one for 96 hours (point not shown). Values plotted as mean \pm standard error of the mean.

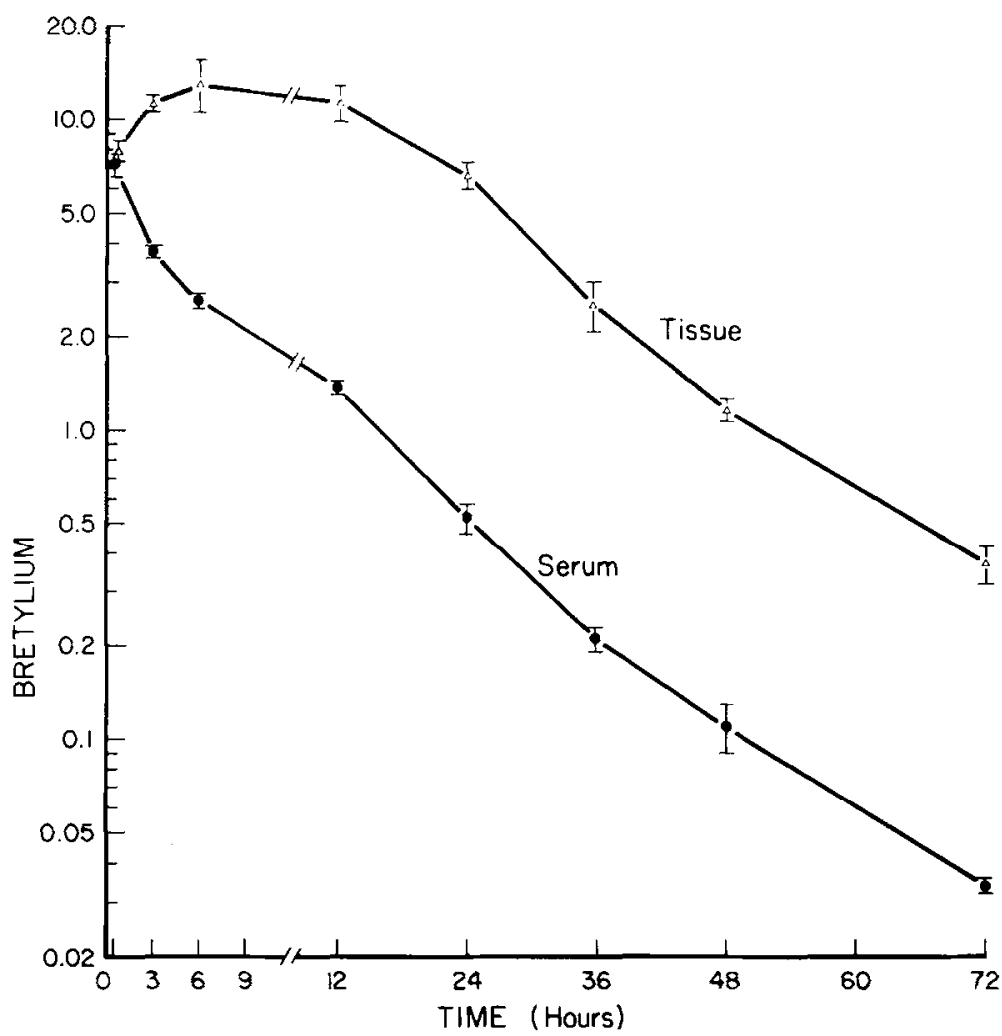

( $\mathrm{p}=0.046$, analysis of variance). Response after injection of saline solution was flat over time, with mean effective refractory periods of 151 to $153 \mathrm{~ms}$. In contrast, after administration of $6 \mathrm{mg} / \mathrm{kg}$ of the drug (four dogs), the refractory period increased from $156 \pm 3$ at 0 minute and $158 \pm 1$ at 30 minutes to $171 \pm 4 \mathrm{~ms}$ at 90 minutes. The peak effective refractory period obtained at 3 hours $(177 \pm 3 \mathrm{~ms})$ persisted at 6 hours $(174 \pm 4 \mathrm{~ms})$ and declined (to $164 \pm 4 \mathrm{~ms}$ ) by 12 hours. Increases after administration of $2 \mathrm{mg} / \mathrm{kg}$ of the drug (six dogs) were slightly but not significantly less than those after 6 $\mathrm{mg} / \mathrm{kg}$, but were significantly greater $(90$ minutes to 6 hours) than those after administration of saline solution (Scheffe).

Control ventricular response threshold averaged 0.11 $\pm 0.01 \mathrm{~mA}$ (16 dogs), and varied in a fashion similar to effective refractory period. The response threshold was invariant after fibrillation threshold determinations and over the 12 hour study period after injection of saline solution, but tended to increase after administration of bretylium. The peak response threshold occurred at 6 hours, averaging $0.17 \pm 0.02 \mathrm{~mA}$ after $2 \mathrm{mg} / \mathrm{kg}$ and 0.18 \pm 0.03 after $6 \mathrm{mg} / \mathrm{kg}$ of the drug was given. These changes were not quite significant ( $p=0.05$ to 0.10 ).

Effects on ventricular fibrillation threshold: Marked increases in ventricular fibrillation threshold developed after injection of bretylium tosylate (Fig. 5). Differences in response among the groups treated with bretylium and the cortrol group treated with saline solution were obviously highly significant from $2 \mathrm{~min}$ utes to 12 hours ( $p<0.001$, analysis of variance) (Table I).
At 2 minutes after injection of $6 \mathrm{mg} / \mathrm{kg}$ of the drug (nonischemic conditions), ventricular fibrillation could be elicited in two dogs (at $35 \mathrm{~mA}$ and $40 \mathrm{~mA}$, respectively) but not in another two dogs (greater than $50 \mathrm{~mA}$ ) ( $p=0.002$, control time versus 2 minutes). Complete protection from ventricular fibrillation at $50 \mathrm{~mA}$ continued thereafter throughout 12 hours of observation in the nonischemic state in all four animals. With 2 minutes of coronary ischemia, the heart of one of four

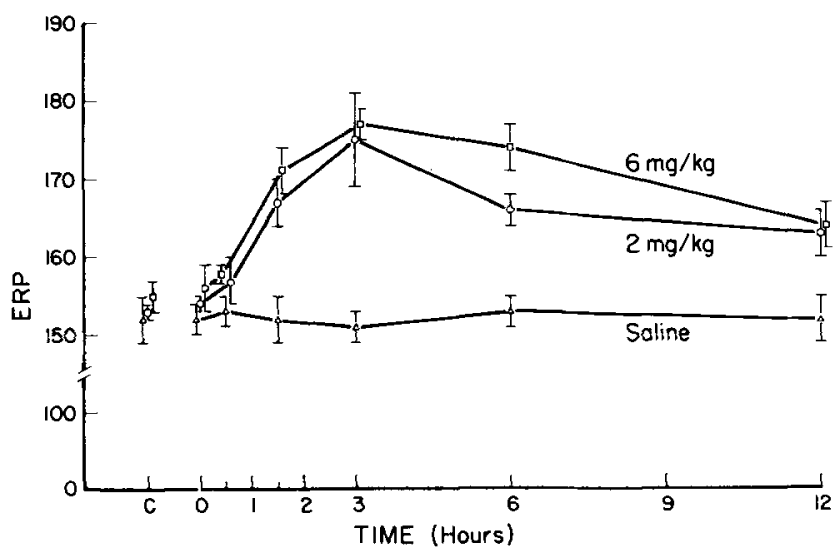

FIGURE 4. Effective refractory period (ERP) plotted in $\mathrm{ms} \pm$ standard error of the mean versus time. Control time $\mathrm{C}$ is before drug administration and initial ventricular fibrillation threshold determination. Control time 0 is after initial determination of fibrillation threshold and directly before drug administration. Other times are 2, 30 and 90 minutes and 3,6 and 12 hours. Groups include four dogs receiving $6 \mathrm{mg} / \mathrm{kg}$ of bretylium, six receiving $2 \mathrm{mg} / \mathrm{kg}$ and six receiving saline solution. 


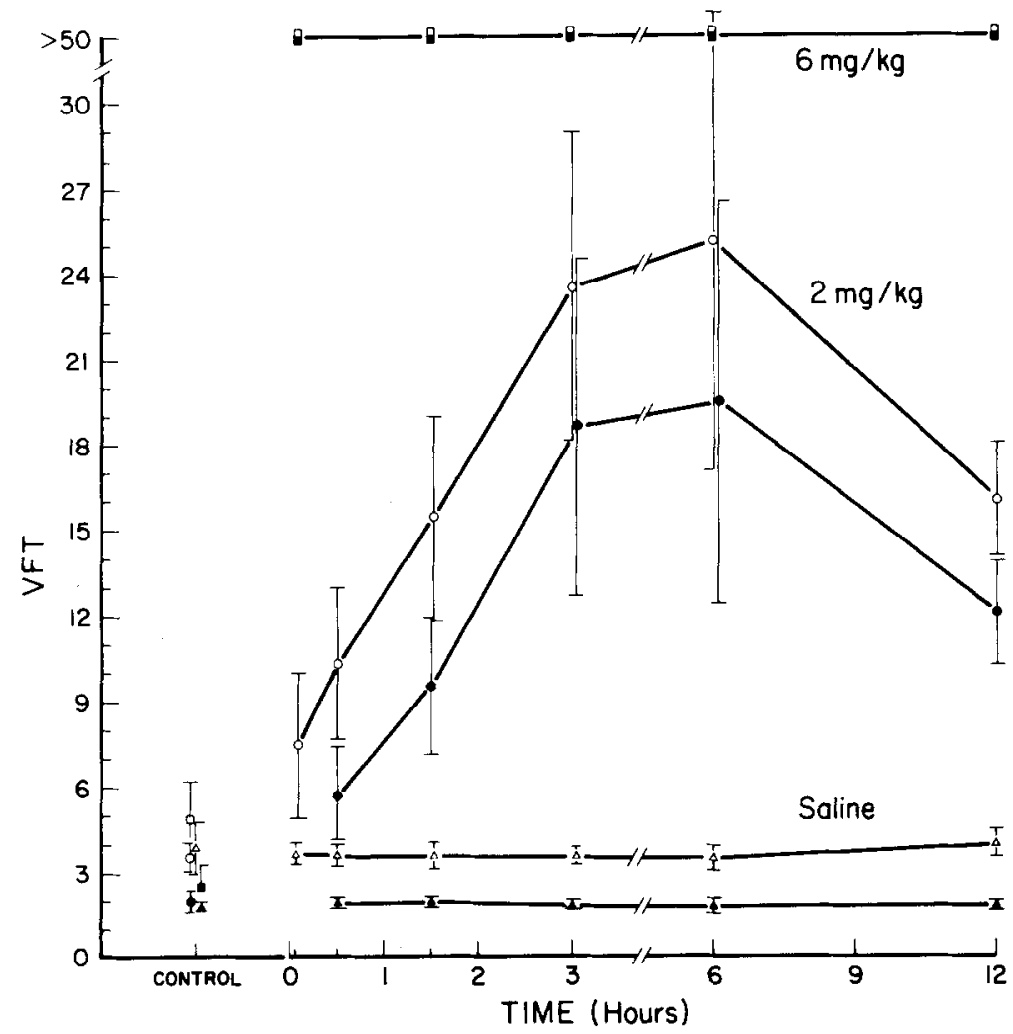

FIGURE 5. Ventricular fibrillation threshold (VFT) response in $\mathrm{mA}$ with time after acute injection of $6 \mathrm{mg} / \mathrm{kg}$ (four dogs) or $2 \mathrm{mg} / \mathrm{kg}$ (six dogs) of bretylium or of saline solution (six dogs). Open symbols represent nonischemic and closed symbols represent ischemic ( 2 minutes) conditions (see text). Values are plotted as mean \pm standard error of the mean. The control measurement is before drug administration; first measurement after drug administration is at 2 minutes (nonischemic). The mean ventricular fibrillation threshold for the group receiving bretylium is greater than $50 \mathrm{~mA}$, which is above the range of determination. See text for individual variations.

TABLE I

Ventricular Fibrillation Threshold (mA) Without and With lschemia*

\begin{tabular}{|c|c|c|c|c|c|c|c|}
\hline \multicolumn{8}{|c|}{ Group I (saline-treated control group) } \\
\hline Dog & Control $(0)$ & $2 \min$ & $30 \mathrm{~min}$ & $90 \mathrm{~min}$ & $3 \mathrm{~h}$ & $6 \mathrm{~h}$ & $12 \mathrm{~h}$ \\
\hline $\begin{array}{c}1 \\
2 \\
3 \\
4 \\
5 \\
6 \\
\text { Mean (Dogs 1-6) } \\
\text { I SEM (NI/l) }\end{array}$ & $\begin{array}{l}3.0 / 2.0 \\
4.5 / 2.0 \\
2.0 / 2.0 \\
3.5 / 1.0 \\
4.0 / 1.5 \\
4.5 / 1.5 \\
3.6 \pm 0.4 / \\
1.7 \pm 0.2\end{array}$ & \begin{tabular}{l}
$3.5 /-$ \\
$4.0 /-$ \\
$2.5 /-$ \\
$4.0 /-$ \\
$3.5 /-$ \\
$4.5 /-$ \\
$3.7 \pm 0.4 /$ \\
\multicolumn{1}{c}{}
\end{tabular} & $\begin{array}{l}3.0 / 2.5 \\
4.0 / 2.5 \\
2.0 / 2.0 \\
4.5 / 1.0 \\
3.5 / 1.5 \\
4.5 / 2.0 \\
3.6 \pm 0.4 / \\
1.9 \pm 0.2\end{array}$ & $\begin{array}{l}3.5 / 2.0 \\
5.0 / 3.0 \\
2.0 / 1.5 \\
3.0 / 1.0 \\
3.5 / 1.5 \\
4.5 / 2.0 \\
3.6 \pm 0.5 / \\
1.8 \pm 0.3\end{array}$ & $\begin{array}{l}3.5 / 2.5 \\
4.0 / 2.0 \\
2.5 / 2.0 \\
3.5 / 1.0 \\
4.0 / 1.5 \\
4.0 / 1.5 \\
3.6 \pm 0.2 / \\
1.8 \pm 0.2\end{array}$ & $\begin{array}{l}3.5 / 2.0 \\
3.5 / 1.5 \\
2.0 / 2.0 \\
3.0 / 1.0 \\
4.0 / 1.5 \\
5.0 / 2.0 \\
3.5 \pm 0.4 / \\
1.7 \pm 0.2\end{array}$ & $\begin{array}{r}3.5 / 2.0 \\
6 / 2.5 \\
2.5 / 2.0 \\
3.5 / 1.0 \\
4.0 / 1.5 \\
4.5 / 2.0 \\
4.0 \pm 0.5 / \\
1.8 \pm 0.2\end{array}$ \\
\hline \multicolumn{8}{|c|}{ Group II (small dose [ $2 \mathrm{mg} / \mathrm{kg}$ ] bretylium-treated) } \\
\hline $\begin{array}{c}7 \\
8 \\
9 \\
10 \\
11 \\
12 \\
\text { Mean (Dogs } 7-12) \\
\pm \text { SEM }(\mathrm{NI} / \mathrm{I}) \\
\end{array}$ & $\begin{array}{l}2.5 / 2.5 \\
2.0 / 1.0 \\
4.0 / 2.0 \\
5.0 / 3.5 \\
4.0 / 2.0 \\
4.0 / 1.5 \\
3.6 \pm 0.5 / \\
2.1 \pm 0.4\end{array}$ & $\begin{array}{l}2.0 /- \\
1.5 /- \\
4.5 /- \\
18 /- \\
9 /- \\
10 /- \\
7.5 \pm 2.5 / \\
-\end{array}$ & $\begin{array}{c}1.5 / 3.0 \\
4.5 / 3.0 \\
16 / 2.0 \\
16 / 12 \\
8 / 4.0 \\
16 / 10 \\
1.3 \pm 2.7 / \\
5.7 \pm 1.7\end{array}$ & $\begin{array}{c}2.5 / 2.5 \\
9 / 8 \\
18 / 4.5 \\
22 / 18 \\
16 / 10 \\
25 / 14 \\
15.5 \pm 3.4 / \\
9.5 \pm 2.4\end{array}$ & $\begin{array}{c}3.0 / 4.5 \\
18 / 16 \\
40 / 45 \\
25 / 20 \\
20 / 8 \\
35 / 18 \\
23.5 \pm 5.4 / \\
18.6 \pm 5.8\end{array}$ & $\begin{array}{c}5.0 / 4.5 \\
20 / 16 \\
>50 />50 \\
20 / 16 \\
10 / 6 \\
35 / 25 \\
25.0 \pm 8.2 / \\
21.3 \pm 8.3\end{array}$ & $\begin{array}{c}16 / 12 \\
16 / 12 \\
20 / 16 \\
18 / 12 \\
6 / 4.0 \\
20 / 16 \\
16.0 \pm 2.1 / \\
12.0 \pm 4.4\end{array}$ \\
\hline \multicolumn{8}{|c|}{ Group III (large dose [6 mg/kg] bretylium-treated) } \\
\hline $\begin{array}{c}13 \\
14 \\
15 \\
16 \\
\text { Mean (Dogs 13-16) } \\
\pm \text { SEM (NI/I) }\end{array}$ & $\begin{array}{l}9 / 5.0 \\
3.0 / 1.5 \\
4.0 / 2.0 \\
3.0 / 1.5 \\
4.8 \pm 1.4 / \\
2.5 \pm 0.8\end{array}$ & $\begin{aligned}> & 50 /- \\
> & 50 /- \\
& 35 /- \\
& 40 /- \\
> & 50 /-\end{aligned}$ & $\begin{array}{l}>50 />50 \\
>50 / 18 \\
>50 />50 \\
>50 />50 \\
>50 / \geq 50\end{array}$ & $\begin{array}{l}>50 />50 \\
>50 />50 \\
>50 />50 \\
>50 />50 \\
>50 />50\end{array}$ & $\begin{array}{l}>50 />50 \\
>50 />50 \\
>50 />50 \\
>50 />50 \\
>50 />50\end{array}$ & $\begin{array}{l}>50 />50 \\
>50 />50 \\
>50 />50 \\
>50 />50 \\
>50 />50\end{array}$ & $\begin{array}{l}>50 />50 \\
>50 / 40 \\
>50 / 35 \\
>50 />50 \\
>50 / \geq 50\end{array}$ \\
\hline
\end{tabular}

* Individual ventricular fibrillation threshold response is given in milliamperes (mA) at times indicated after drug or saline injection for dogs in groups I to III. For each time, the number to the left of the slash indicates the value without ischemia (NI) and the number to the right of the slash indicates the value after 2 minutes of coronary ischemia (I) (that is, nonischemic/ischemic). 
FIGURE 6. Repetitive ventricılar response (RVR) threshold ( $\mathrm{mA}$ ) versus time before (control) and after administration of drug or saline solution. Times and number are similar to those in Figure 5. Results ares plotted as mean \pm standard error of the mean. Open symbols indicate nonischemic, closed symbols ischemic ( 2 minutes) conditions. The first measurement after drug administration is at 2 minutes (nonischemic).

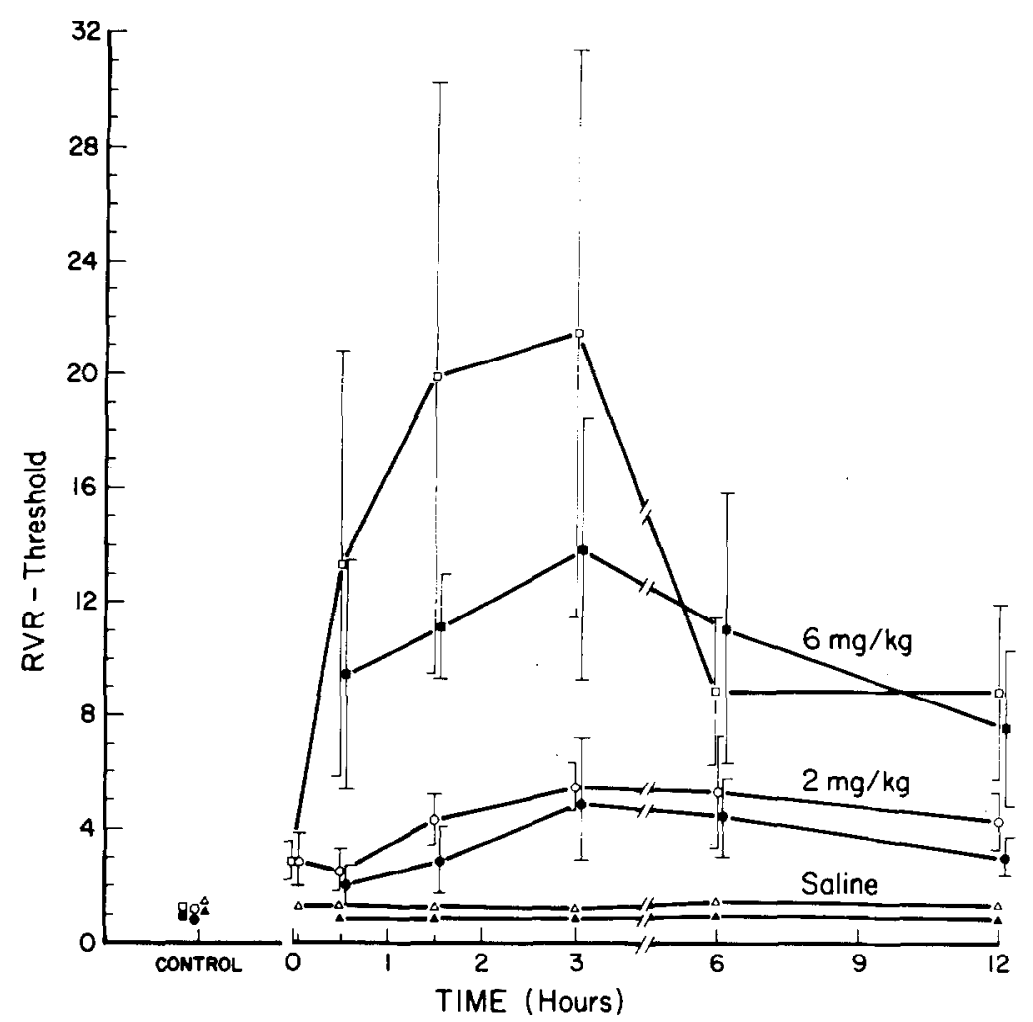

No change occurred in the fibrillation threshold of the seven control animals receiving saline solution with time in either the ischemic or nonischemic state. This response in control animals verifies the stability of ventricular fibrillation threshold over at least 12 hours in these open chest preparations. The threshold with ischemia (1.7 to $1.9 \mathrm{~mA}$, range of the mean) was approximately half of that without ischemia ( 3.5 to $4.0 \mathrm{~mA}$, range of the mean) and differed significantly at each timed determination ( $t$ test). This finding confirms the deleterious effect of ischemia on ventricular fibrillation threshold.

Effects on repetitive ventricular response threshold: The effect of bretylium on the repetitive ventricular response threshold as defined in Methods is shown in Figure 6. After injection $6 \mathrm{mg} / \mathrm{kg}$ of bretylium tosylate in four dogs, the mean response threshold began to increase by 2 minutes (from $1.3 \pm 0.3$ to $2.8 \pm$ $0.9 \mathrm{~mA})$, peaked at 3 hours $(21.4 \pm 10.0 \mathrm{~mA})$, then decreased but remained elevated above control values at 12 hours $(8.8 \pm 3.2 \mathrm{~mA})$. Significant geometric differences between the bretylium-treated and saline-treated groups were present between 30 minutes and 12 hours ( $\mathrm{p}<0.003, t$ test). After 2 minutes of coronary ischemia, $6 \mathrm{mg} / \mathrm{kg}$ of the drug also raised the response threshold so that at 90 minutes it had increased from $1.3 \pm 0.4$ to $11.1 \pm 3.7 \mathrm{~mA}(\mathrm{p}=0.01)$. The bretylium-treated and saline-treated groups showed differences between 30 minutes and 12 hours ( $t$ test). As expected, the absolute elevation during ischemia was generally lower than during nonischemic conditions.

Elevation in repetitive ventricular response threshold of a lower magnitude developed after 2 


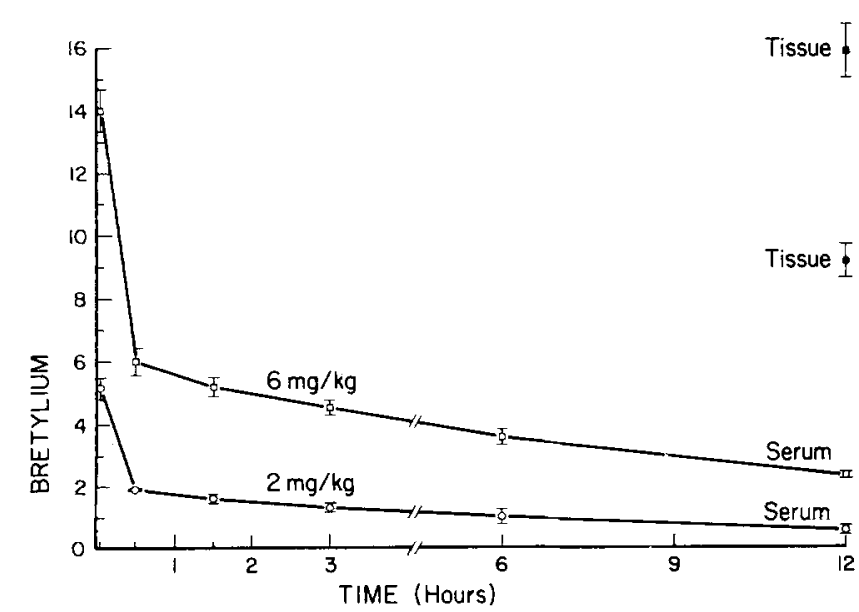

FIGURE 7. Serum $(\mu \mathrm{g} / \mathrm{ml})$ and final myocardial tissue $(\mu \mathrm{g} / \mathrm{g})$ concentrations of bretylium in animals subjected to electrophysiologic testing (Fig. 4 to 6). Results are presented as mean \pm standard error of the mean. Compare also with Fig. 1, A and B.

$\mathrm{mg} / \mathrm{kg}$ of bretylium tosylate. In this group $(\mathrm{n}=6)$ the threshold increased from $1.2 \pm 0.2 \mathrm{~mA}$ in the control period to $4.0 \pm 1.1 \mathrm{~mA}$ at 90 minutes $(\mathrm{p}=0.03)$, and to a maximum of $5.4 \pm 1.9 \mathrm{~mA}$ at 3 hours. Persistent elevation of $4.3 \pm 1.0 \mathrm{~mA}$ was present at 12 hours. The bretylium-treated and saline-treated groups showed significant differences between 90 minutes and 12 hours ( $t$ test). Similarly, augmentation in the response threshold occurred in animals treated with $2 \mathrm{mg} / \mathrm{kg}$ of the drug after coronary ischemia, with control threshold of $0.8 \pm 0.2 \mathrm{~mA}$ rising significantly to $2.0 \pm 0.6$ at 30 minutes $(\mathrm{p}=0.03)$, and further to $4.9 \pm 2.0 \mathrm{~mA}$ at 3 hours. Elevation persisted at 12 hours $(3.0 \pm 0.6 \mathrm{~mA})$. The mean values in the saline- and bretylium-treated groups were significantly different from 90 minutes to 12 hours.

The repetitive ventricular response threshold was stable for 12 hours in the control animals injected with saline solution. Repetitive response was elicited at lower current with ischemia (mean $0.7 \pm 0.1 \mathrm{~mA}$ ) than without ischemia $(1.5 \pm 0.1 \mathrm{~mA})(\mathrm{p}=0.03, t=0)(\mathrm{Fig}$. $6)$.

Previously proposed as a subfibrillatory measure of ventricular fibrillation threshold, repetitive ventricular response threshold followed the general temporal configuration of fibrillation threshold, although at approximately one fourth the current level. The repetitive response data also suggest a proportionate three- to four-fold greater effect of the three-fold greater dose of bretylium sall ( $6 \mathrm{mg} / \mathrm{kg}$ versus $2 \mathrm{mg} / \mathrm{kg}$ ). However, in contrast to mean results, the relation of repetitive ventricular response and ventricular fibrillation thresholds in individual animals was too variable to be of much predictive value. Only at 30 and 90 minutes with ischemia (in animals receiving $2 \mathrm{mg} / \mathrm{kg}$ ) was there an individual correlation of these two thresholds $(p=$ $0.05)$.

Serum and tissue bretylium in animals tested for ventricular fibrillation threshold: Serial serum concentrations of bretylium measured at the time of ventricular fibrillation threshold determinations for the four animals receiving $6 \mathrm{mg} / \mathrm{kg}$ and the six animals receiving $2 \mathrm{mg} / \mathrm{kg}$ of the drug are presented in Figure 7 . In addition, myocardial (left ventricular) bretylium concentrations at the time the dogs were killed (12 hours) are shown. There is no significant difference between these serum concentration curves and those presented in Figure 1 for the tissue pharmacokinetic study. Tissue levels at 12 hours were likewise similar. Once again, the mean final (12 hour) tissue to serum ratio was greater for the group receiving $2 \mathrm{mg} / \mathrm{kg}$ than for the group recciving $6 \mathrm{mg} / \mathrm{kg}(17.9 \pm 3.9$ versus $6.9 \pm$ 1.8). It may thus be presumed that the detailed tissue kinetics determined as in Figure 1 apply to the group subjected to ventricular fibrillation threshold determinations.

As expected, a variable (usually modest) increase in blood pressure and heart rate occurred seconds to minutes after drug administration. In all cases, these changes had returned to baseline within 30 minutes. The kinetics of ventricular fibrillation threshold elevation were thus distinct from those of the catecholamine release reaction.

\section{Discussion}

Role of myocardial drug concentration in determining therapeutic effects: These kinetic studies emphasize the importance of drug concentrations at tissue sites of action in myocardium in determining therapeutic effects. Whereas serum bretylium concentration decreased rapidly after intravenous injection, both myocardial bretylium concentration and antifibrillatory and electrophysiologic effects increased gradually, peaking at approximately 3 hours. These kinetic results were similar with or without myocardial ischemia and for both doses of bretylium. Bretylium was heavily concentrated in myocardial tissue (6 to 18-fold), suggesting that small changes in serum bretylium at equilibrium might be associated with wide and variable swings in tissue concentration. In addition, conditions of pseudoequilibrium (parallel elimination) in tissue and serum compartments were not obtained until 12 to 24 hours after short-term dosing, as demonstrated in the 72 hour dog model with subsequent elimination half-life in tissue and serum of 10.5 hours. In summary, serum bretylium concentrations after short-term dosing are not predictive of drug effects, whereas an understanding of tissue drug kinetics and concentrations appears to be very useful.

Effect of bretylium on ventricular fibrillation threshold: Bretylium caused marked increases in ventricular fibrillation threshold, confirming its reported efficacy as an antifibrillatory agent. ${ }^{15,18-20}$ The canine model used confirms the deleterious effect of ischemia on fibrillation threshold ${ }^{21}$ and documents a relatively equipotent therapeutic effect in the ischemic and the nonischemic heart. The responses observed suggest incremental effects on fibrillation threshold of increasing doses of bretylium, in the range tested. Our canine preparation proved to be a highly stable model for threshold determinations over the 12 hour period of observation. 
The repetitive ventricular response threshold was a useful predictor of group response of ventricular fibrillation threshold to drug. However, in the individual animal, the correlation was too variable to be useful. In general, at least a proportionate rise in antiarrhythmic effect is predicted by the repetitive ventricular response as the dose is increased from 2 to $6 \mathrm{mg} / \mathrm{kg}$. The data on repetitive ventricular response also suggest that peak drug effect after $6 \mathrm{mg} / \mathrm{kg}$, similar to that of a smaller dose, occurs at approximately 3 hours.

The time course of change in effective refractory period was similar to that for ventricular fibrillation and repetitive response thresholds. However, increases in refractory period were not proportionate to increases in drug concentration. The parallel temporal change of effective refractory period and fibrillation threshold suggests a correlation between drug effect on effective refractory period and on fibrillation threshold. On the other hand, incremental change in refractory period using $6 \mathrm{mg} / \mathrm{kg}$ in comparison with $2 \mathrm{mg} / \mathrm{kg}$ was much less than that for fibrillation threshold. These observations suggest a nonlinear relation between these two measures of drug effect or the importance of factors in addition to changes in refractory period in determining ventricular fibrillation threshold.

These studies demonstrate the utility of endomyocardial biopsy in allowing long-term observations of drug kinetics in myocardial tissue. Information derived may be particularly useful for clinical comparisons. Our observations confirmed the long persistence of drug in myocardium after single dosing, with detectable drug persisting for more than 72 to 96 hours.

Mechanism of bretylium's cardiac effects: Controversy continues to exist as to whether bretylium has important direct effects on the human heart independent of its action on the adrenergic neuron. ${ }^{3,4}$ Experimental work suggests that both direct electrophysiologic effects and myocardial concentration of drug are independent of cardiac nerves. ${ }^{8,22,23}$ Cardinal and Sasyniuk ${ }^{9}$ showed that bretylium increases action potential and refractory period duration in isolated Purkinje fibers, and reduces the disparity in local action potential duration between normal and infarct preparations. Namm et al., ${ }^{22}$ using immunosiympathectomized rats, showed the marked myocardial concentrations of bretylium to be independent of cardiac sympathetic nerve uptake. Electrophysiologic effects, including lengthening of effective refractory period and action potential duration, were also similar in both normal and immunosympathectomized animals. Bretylium was found to bind to cell plasma membranes in a tight but reversible fashion. Our observations lend support to those of these workers, and suggest that the kinetics of electrophysiologic and antifibrillatory effects of bretylium parallel those of drug accumulation in myocardial tissue. In contrast, the kinetics of catecholamine release and serum drug are dissimilar.

Serum versus myocardial drug kinetics: Detailed studies of myocardial tissue kinetics of other antiarrhythmic drugs have not come to our attention. The relation between serum drug kinetics and drug action after short-term administration varies among these agents. With drugs such as lidocaine, a direct temporal relation appears to exist. Schnittger et al. ${ }^{24}$ demonstrated a linear relation between plasma lidocaine concentrations during acute infusions and increases in ventricular fibrillation threshold. With other drugs such as bretylium, acute effects are dissociated from blood kinetics and maximal effects may be substantially delayed. The antiarrhythmic effect of amiodarone does not become evident until 4 to 8 days after therapy is begun. ${ }^{25}$ Intravenous propranolol may yield immediate therapeutic benefit, but plasma concentrations do not correlate simply with drug effects. ${ }^{25}$ Lameijer and van Zweiten $^{27}$ found slow (1 to 3 hours), 10-fold concentration of quinidine in the isolated mammalian heart and parallel temporal changes in refractory period. Strauss et al..$^{28}$ found procainamide to be concentrated in myocardium in a ratio of $2.3: 1$, after a 4 hour loading infusion, but kinetics were not studied. Further studies of myocardial tissue kinetics of these drugs would be of interest.

Clinical implications: Our study in dogs demonstrates marked time- and dose-dependent differences in response to bretylium tosylate. Clinical extrapolation of these data as in other animal studies must be tentative. However, clinical implications might include the need for repeated acute drug dosing and allowance of greater time after acute bretylium administration before assuming drug failure. Current package insert recommendations reflect this implication. ${ }^{29}$ Thus, if the initial $5 \mathrm{mg} / \mathrm{kg}$ bolus injection of bretylium is ineffective in restoring rhythm, additional dosing up to $30 \mathrm{mg} / \mathrm{kg}$ total over about 30 minutes is suggested. ${ }^{29}$ The delayed response in ventricular fibrillation threshold rise seen with our small dose might thereby be converted to an immediate response similar to that seen with our larger dose (Fig. 5). This study confirms the utility and sensitivity of a new drug assay for bretylium using a gas recently described chromatographic method. ${ }^{13} \mathrm{~A}$ more rational approach to administration of bretylium in patients should result from clinical application of this assay and further testing of the inferences suggested by this study.

\section{Acknowledgment}

We thank Linda Jallad for typing the manuscript. We appreciate the helpful assistance and suggestions of Richard Lampman, PhD and Anthony Schork, PhD.

\section{References}

1. Anderson JL, Harrison CIC, Meffin PJ, Winkle RA. Antiarrhythmic drugs; clinical pharmacology and therapeutic uses. Drugs 1978; 15:271-309.

2. Harrison DC, Metfin PJ, Winkle RA. Clinical pharmacokinetics of antiarrhythmic drugs. Prog Cardiovasc Dis 1978;20:217-42.
3. Koch-Weser J. Drug therapy: bretylium. N Engl J Med 1979; 300:473-7.

4. Heissenbuttel RH, Bigger JT. Bretylium tosylate: a newly available antiarrhythmic drug for ventricular arrhythmias. Ann Intern Med 1979:91:229-38. 
5. Bacaner MB. Quantitative comparison of bretylium with other antifibrillatory drugs. Am J Cardiol 1968;21:504-12.

6. Boura ALA, Green AF. The actions of bretylium: adrenergic neuron blocking and other effects. Br J Pharmacol 1959;14:536-48.

7. Chatterjee K, Mandel WJ, Vyden JK, Parmley WW, Forrester JS. Cardiovascular effects of bretylium tosylate in acute myocardial infarction. JAMA 1973;223:757-60.

8. Gokhale SD, Gulati OD, Kelkar VV. Mechanism of the initial adrenergic effects of bretylium and guanethidine. $\mathrm{Br} J$ Pharmacol $1963 ; 20: 362-77$

9. Cardinal R, Sasyniuk B. Electrophysiological effects of bretylium tosylate on subendocardial Purkinje fibers from infarcted canine hearts. J Pharmacol Exp Ther 1977;204:159-74.

10. Bigger JT, Jaffe CC. The effect of bretylium tosylate on the electrophysiologic properties of ventricular muscle and Purkinje fibers. Am J Cardiol 1971;27:82-92.

11. Lucchesi BR. Antiarrhythmic drugs, In: Antonaccio M, ed. Cardiovascular Pharmacology. New York: Raven Press, 1977:269.

12. Lucchesi BR. Electropharmacology of drugs used in the treatment of ventricular arrhythmias. U Mich Med Cent J 1978;44:54-9.

13. Patterson E, Stetson PL, Lucchesi BR. A sensitive gas chromatographlc assay for the quantitation of bretylium in plasma, urine and myocardial tissue. J Chromatogr 1980;181:33-9.

14. Mason JW. Techniques for right and left ventricular endomyocardial biopsy. Am J Cardiol 1978;41:887-92.

15. Kniffen FJ, Lomas TE, Counsell RE, Lucchesi BR. The antiarrhythmic and antifibrillatory actions of bretylium and its o-iodobenzyl trimethylammonium analog, UM-360. J Pharmacol Exp Ther 1975;192:120-8.

16. Kroll DA, Lucchesi BR. Antiarrhythmic and antifibrillatory properties of aprindine. J Pharmacol Exp Ther 1975:194:427-34.

17. Scheffe H. Analysis of Variance. New York: Wiley \& Sons, 1959:68

18. Holder DA, Sniderman AD, Fraser DG, Fallen E. Experience with bretylium tosylate by a hospital cardiac arrest team. Circulation 1977:55:541-4.
19. Bernstein JG, Koch-Weser J. Effectiveness of bretylium tosyiate against refractory ventricular arrhythmias. Circulation 1972;45: 1024-34.

20. Romhilt DW, Bloomfleid SS, Lipicky RJ, Welch RM, Fowler NO. Evaluation of bretylium tosylate for the treatment of premature ventricular contractions. Circulation 1972;45:880-907.

21. Gaum WE, Elharrar V, Walker PD, Zipes DP. Influence of excitability on the ventricular fibrillation threshold in dogs. Am J Cardiol 1977;40:931-5

22. Namm DH, Wang CM, Sayad S, Copp FC, Maxwell RA. Effects of bretylium on rat cardiac muscle: the electrophysiological effects and its uptake and binding in normal and immunosympathectomized rat hearts. J Pharmacol Exp Ther 1974:193:194-207.

23. Boura ALA, Copp FC, Duncombe WG, Green AF, McCoubrey A. The selective accumulation of bretylium in sympathetic ganglia and their post-ganglionic nerves. J Pharmacol 1960;15:265-70.

24. Schnittger I, Griffin JC, Hall RJ, Meffin PJ, Winkle RA. Effects of tocainide on ventricular fibrillation threshold. Am J Cardiol $1979 ; 42: 76-80$

25. Rosenbaum MB, Chiale PA, Halpern MS, et al. Clinical efficacy of amiodarone as an antiarrhythmic agent. Am J Cardiol 1976; 38:934-44.

26. Woosley RL, Kornhauser, Smith R, et al. Suppression of chronic ventricular arrhythmias with propranolol. Circulation 1979;60: 819-27.

27. Lameljer W, van Zwelten PA. Comparison between the tissue uptake of quinidine and its influence on the refractory period in isolated heart muscle. Arch Int Pharmacodyn Ther 1974;210: 321-32.

28. Strauss AC, Bache RJ, Masterton CE, Abou-donla MB, McHale PA, Menzel DB. Radiochemical determination of $\left[{ }^{14} \mathrm{C}\right]$ procainamide in canine myocardium. Am J Physiol 1978;239:H399H403.

29. Package insert, Bretylo ${ }^{\circledR}$ brand of bretylium tosylate, Arnar-Stone Labs, Inc, Nov 1978. 